\title{
Elections to the Fellowship, 1984-1985
}

The Members listed below have registered as Fellows of the College following their election by the Court of Electors.

\section{4}

J. G. Andrews, C. B. Ballinger, E. R. Banner, G. Beaumont, O. Ben-Arie, G. Bennet, H. M. Bower, A. D. Broadhurst, H. K. H. Brodie, P. W. Burvill, G. J. Calvert, P. G. Cannon, A. B. Christie, I. G. Christie, C. N. Christodoulou, R. Chynoweth, R. B. Crossley, M. Crowe, W. A. Dalgleish, J. D. Denford, D. M. Dickens, I. G. Dresser, M. T. Duff-Miller, R. D. Eastham, E. L. Edelstein, W. Falkowski, C. Fazio, T. W. Fenton, R. A. Franklin, B. J. Gurland, D. Hall, B. G. Harwin, D. E. N. Hassall, A. S. Henderson, E. P. HilaryJones, I. Husain, R. E. S. James, B. C. A. Johnson, E. C. Johnstone, D. Jones, H. Smyrna Jones, R. Kellner, L. M. Kremer, G. L. Lipton, G. G. Lloyd, J. Lomax-Simpson, J. Loudon, G. C. Lyketsos, R. Maclean, P. D. Maddocks, A. H. Mann, F. M. Marks, J. Marks, C. McDonald, R. A. Meares, J. P. Mellon, B. J. Muir, A. N. Munro, C. D. Neal, N. Neophytou, P. N. Nott, K. O’Keeffe, G. Oppenheim, R. L. Palmer, J. B. Pearce, R. Pinto, T. Pitt-Aikens, A. J. Poole, M. Quasim, B. Raphael, P. O. Reeves, Gwyn Roberts, W. Rodger, R. Rosser, A. M. Rouncefield, L. F. Rowe, A. Sadek, R. J. Schureck, A. Sippert, O. Somasundaram, G. W. Thompson, I. G. Thomson, J. Todd, C. Todes, K. L. K. Trick, J. Trowell, J. Tsiantis, D. J. Ward, H. Warnes, D. M. D.
White, Y. V. Wiley, V. A. Wilkinson, A. R. Wilson, S. Wiseberg, Sze Tai Wong, E. C. Wright, J. D. Young, G. D. P. Wallen.

\section{5}

P. L. Agulnik, P. Ainsworth, J. M. A. Ansari, B. H. Anstee, R. P. Arya, R. P. Aylett, A. N. Bale, R. G. Bankier, E. H. Bennie, D. A. Bennett, S. Bhanji, S. R. Bhate, D. Black, R. C. Bland, S. Bloch, T. J. R. Bruce, J. R. Burgess, F. Caldicott, H. Caplan, B. J. Carroll, C. N. Chen, A. W. Clare, J. P. Cobb, A. F. Cooper, M. Cordero, J. Elliot, P. M. Fleming, R. Fleminger, P. Flor-Henry, M. W. Forth, A. J. Gardner, D. Gaspar, H. Ghodse, S. Gluzman, J. R. Gomez, W. P. Gurassa, J. Harris, S. Heath, J. Heron, H. I. Hershon, E. R. Herst, J. Higgins, S. J. Hucker, P. V. Hunt, R. I. Kennedy, A. Koryagin, R. Kumar, J. H. Lacey, F. Lappin, R. G. McCreadie, G. P. McGovern, W. K. Marshall, A. B. Masters, M. C. Mitcheson, R. Morgan, C. Q. Mountjoy, A. M. Myers, E. D. Myers, H. Neubauer, J. R. Noble, C. M. H. Nunn, H. A. Panahloo Saidabadi, A. L. Phanjoo, J. Picton-Jones, D. Prothero, E. H. Reynolds, M. R. Riahinejad, J. W. Rollins, J. A. O. Russell, S. Sandberg, U. P. Seidel, R. Seymour-Shove, M. Shafique, M. Sharif, Z. Slattery, J. Sneddon, G. Stewart, J. D. Stirland, A. Tarnopolsky, E. Taws, M. Vanyan, R. M. Walters, J. A. G. Watt, A. West, R. Whyte, S. R. Wilson, D. H. Yates.

\section{Procedure for Application to the Categories of New Affiliates and New Associates}

Under the revised Bye-Laws, it is now possible for the College to elect New Affiliates and New Associates. No more than ten of each may be elected in one year, and no more than one hundred of each may be registered at any time.

New Affiliates must be medically qualified, and New Associates must be non-medically qualified. The Court of Electors has suggested that, in general, New Affiliates are not necessarily expected to be psychiatrists. Both groups should be drawn from distinguished members of their professions whose work is related to psychiatry, in practice or research, and who would be regarded as valuable contributors to the work and standing of the College.

New Affiliates and New Associates pay an annual subscription to the College: at present this is $£ 60$ and $£ 35$ respectively.
They receive the Journal and Bulletin and notices of all general, quarterly and scientific meetings, which they can attend. They can join appropriate sections of the College. They do not have a vote in the affairs of the College.

A person can apply to the Court of Electors for registration. The applicant should include a brief curriculum vitae, on a form obtainable from the College, together with the names of two Members or Fellows of the College (who should not be members of the Court of Electors) who would be willing to support their application. These will then be approached, in confidence, by the College.

All applications should be completed and sent to the Registrar at the College by 30 September each year, for consideration the following year.

\section{Advice on Research}

A revised and expanded set of notes which might be of help to those planning research projects is now available. It is entitled 'Hints on Research' and is available free from the Research Committee of the College.

The Research Committee would also like to remind $\mathrm{mem}$ bers that it is very willing to try and help members who have queries about research matters or who are having difficulty finding advice about a particular research project. The Committee cannot offer any financial support for research nor can it offer regular supervision of projects, but it can try and put members in touch with experienced researchers or experts in particular areas of psychiatric research.

Chris Freeman Secretary, Research Committee 